\title{
The role of IGF-1 for fracture risk in men
}

\section{Liesbeth Vandenput, Klara Sjögren, Johan Svensson and Claes Ohlsson*}

Department of Internal Medicine, Institute of Medicine, Centre for Bone and Arthritis Research, Sahlgrenska Academy, University of Gothenburg, Gothenburg, Sweden

\section{Edited by:}

Bo Abrahamsen, Gentofte Hospital,

Denmark

\section{Reviewed by:}

Elaine Dennison, MRC Lifecourse

Epidemiology Unit, UK

Peter Vestergaard, Aarhus University

Hospital, Denmark

\section{*Correspondence:}

Claes Ohlsson, Department of Internal Medicine, Institute of

Medicine, Centre for Bone and Arthritis Research, University of

Gothenburg, Vita Stråket 11, SE-413

45 Gothenburg, Sweden.

e-mail: claes.ohlsson@medic.gu.se
Growth hormone and insulin-like growth factor-1 (IGF-1) are essential for the achievement of normal longitudinal bone growth and bone mass. Preclinical studies using various knockout models have shown that both endocrine (mostly liver-derived) IGF-1 and bone-derived IGF-1 contribute to normal longitudinal skeletal growth and cortical bone size. Since bone size is an important determinant of bone strength, and hence fracture risk, we evaluated the predictive role of serum IGF-1 for fracture risk. The population-based Osteoporotic Fractures in Men Sweden cohort recently showed for the first time that older men with low serum IGF-1 levels have an increased fracture risk, especially for the two most important fracture types, hip and vertebral fractures. This association between serum IGF-1 and incident fracture risk is partly mediated via bone mineral density. Future studies are required to identify the mechanisms by which endocrine and local IGF-1 regulate skeletal growth and bone size. In addition, possible mediators affecting the impact of IGF-1 on fractures in men remain to be elucidated.

Keywords: bone, insulin-like growth factor-1, population studies, aging, mouse knockout models

\section{INTRODUCTION}

Insulin-like growth factor-1 (IGF-1) is a key mediator of the growth-promoting effects of growth hormone $(\mathrm{GH})$. It is produced in virtually every tissue of the body, including bone, with the liver being the principal source of IGF-1 in the blood. IGF-1 is considered to be essential for longitudinal bone growth, skeletal maturation, and bone mass acquisition during growth and the maintenance of bone mass in adults (Giustina et al., 2008; Ohlsson et al., 2009).

Osteoporosis-related fractures constitute an important public health issue, not only in women but also in men. Besides high social and economic costs associated with fractures, mortality is increased in patients with hip and vertebral fractures, even more so in men than in women (Center et al., 1999b).

In this mini-review, we will shortly summarize the role of IGF1 for bone growth and maintenance using animal knockout (KO) models. In addition, our latest findings from population-based cohorts regarding the predictive role of serum IGF-1 for fractures are discussed.

\section{BOTH SERUM AND LOCALLY PRODUCED IGF-1 CONTRIBUTE TO LONGITUDINAL BONE GROWTH AND CORTICAL BONE SIZE}

Systemic as well as locally produced IGF-1 can affect the skeleton. To investigate the relative contribution of systemic versus local IGF-1, transgenic mouse models were developed using the Cre-loxP system. Mouse models with specific inactivation of the igf-1 gene in the liver showed an approximately $75 \%$ reduction in serum IGF-1 levels, confirming that hepatic IGF-1 is the major contributor to circulating IGF-1 levels (Sjögren et al., 1999; Yakar et al., 1999). Despite these decreases in serum IGF1 , postnatal body growth was preserved and bone length was largely unaffected. Serum IGF-1 levels were even more reduced in $\mathrm{KO}$ mouse models of liver-derived IGF-1 combined with acidlabile subunit and/or total IGF binding protein 3 (removing endocrine IGF-1). These mice displayed a modest but significant reduction in total body length (Yakar et al., 2002, 2009). When looking on the bone phenotype in more detail using computed tomography and histomorphometry, the liver-specific IGF$1 \mathrm{KO}$ mice showed a significant reduction in cortical bone mass. Cortical thickness and periosteal circumference were decreased (Sjögren et al., 2002; Yakar et al., 2002), which was associated with reduced bone strength in adult mice (Sjögren et al., 2002). These models indicate a role for endocrine IGF-1 in the regulation of normal longitudinal bone growth and cortical bone size.

The role of local bone-derived IGF-1 was examined in mouse models with osteoblast- or chondrocyte-specific inactivation of IGF-1 (Govoni et al., 2007a,b). These mice displayed reduced femur length $(-7 \%$ in the chondrocyte $\mathrm{KO}$ and $-15 \%$ in the osteoblast KO) while serum IGF-1 levels were unaffected, indicating that IGF-1 from both chondrocytes and osteoblasts participates in the regulation of bone growth. Cortical bone was also affected in these mice, showing reduced bone width and bone mass in both models (Govoni et al., 2007a,b). Thus, local IGF-1 from chondrocytes and osteoblasts seems essential for both normal bone length and width.

Taken together, these models indicate that both circulating (endocrine) IGF-1 and bone-derived IGF-1 are required for normal longitudinal bone growth and optimal accrual of cortical bone. Since both sources of IGF-1 have, to some extent, overlapping growth-promoting effects, they may partly but not completely be redundant for normal longitudinal bone growth (Ohlsson et al., 2009). 
THE PREDICTIVE ROLE OF SERUM IGF-1 FOR FRACTURE RISK Patients with IGF deficiency as a result of deletion or mutation of the IGF1 gene display osteopenia, indicating a role for IGF-1 in bone metabolism (Woods et al., 1996; Bonapace et al., 2003; Walenkamp et al., 2005). Evaluation of the relationship between serum IGF-1 levels and bone mineral density (BMD) yielded conflicting results, with a positive association being found in some studies (Barrett-Connor and Goodman-Gruen, 1998; Janssen et al., 1998; Langlois et al., 1998) whereas no association was found in others (Bennett et al., 1984; Center et al., 1999a). Moreover, the Rancho Bernardo Study (Barrett-Connor and Goodman-Gruen, 1998) and the Framingham Study (Langlois et al., 1998) found positive associations between serum IGF-1 levels and BMD in women but not in men, whereas the same correlation was found in men but not in women in the Rotterdam Study (Janssen et al., 1998).

The various experimental mouse models described above suggest that serum IGF-1 levels contribute to bone growth and the accrual of an optimal cortical bone size. Since the resistance of bone to bending or torsional forces is related exponentially to its diameter, the bone size is an important contributor to bone strength, and ultimately fracture risk (Orwoll, 2003). Therefore, we assessed the available evidence for a predictive value of serum IGF-1 levels for risk of fracture.

Several studies reported lower serum IGF-1 levels in women with prevalent fractures compared with women without fractures (Sugimoto et al., 1997; Munoz-Torres et al., 2001; Kanazawa et al., 2007). The only prospective fracture study to date in women by Garnero et al. (2000) found an association between low baseline IGF-1 levels and increased risk of fractures. Women with serum IGF-1 concentrations below the median $(212 \mathrm{ng} / \mathrm{ml})$ had a relative risk of fracture of 3.1 compared with women with concentrations above the median. Since the study included 435 postmenopausal women of whom only 55 sustained a fracture, it had limited statistical power and was unable to evaluate the association between serum IGF-I and fracture type. To determine the predictive value of serum IGF-1 for fracture risk in men, we followed older men $(n=2902)$ participating in the prospective Osteoporotic Fractures in Men (MrOS) Sweden study for a mean of 3.3 years (Ohlsson et al., 2011). Low serum IGF-1 levels were associated with increased risk of all fractures, hip fractures, and vertebral fractures in these men. The risk of hip and vertebral fractures increased by 45 and $40 \%$ per SD decrease in serum IGF1 , respectively. Serum levels of IGF-1 below but not above the median $(112 \mathrm{ng} / \mathrm{ml})$ were inversely related to the yearly incidence of fractures (Figure 1). The highest risk of fractures was seen for the $25 \%$ of the subjects with serum IGF-1 levels below $85 \mathrm{ng} / \mathrm{ml}$. In addition, the population-attributable risk proportion was $7.5 \%$ for all fractures and $22.9 \%$ for hip fractures. In this cohort, low levels of serum IGF-1 associated not only with increased fracture risk but also with low BMD. Therefore, adjustment for BMD was performed which attenuated the predictive role of serum IGF-1 for hip fractures and vertebral fractures, suggesting that at least part of the association between serum IGF-1 and fracture risk is mediated via BMD. Neuromuscular function and falls may also impact on fracture risk independent of BMD. However, our data

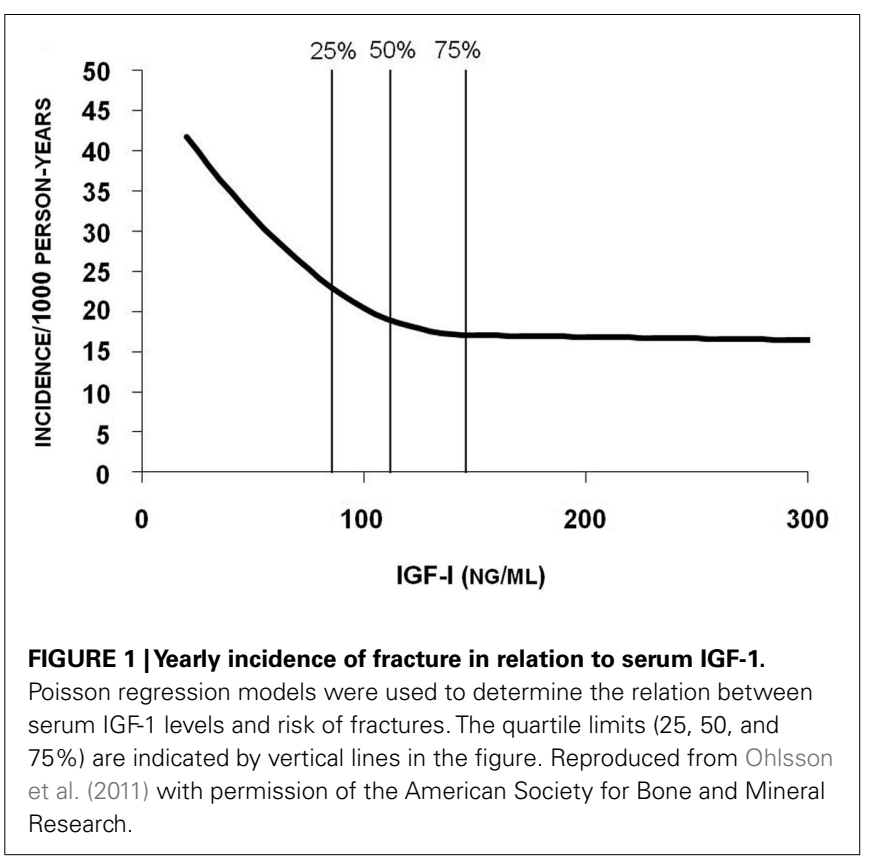

argue against a mediating role of neuromuscular function in the association between serum IGF-1 and fracture risk, since this association was not affected by adjustment for grip strength, total body lean mass, or falls. In conclusion, this well-powered study was the first to show that older men with low serum IGF-1 levels have an increased risk of fractures, especially for the two most important fracture types, hip and vertebral fractures (Ohlsson et al., 2011).

\section{CONCLUSION}

Both systemic and bone-derived IGF-1 play a critical role in normal longitudinal bone growth, bone development, and cortical bone mass accrual, as evidenced by various $\mathrm{KO}$ mouse models. Future studies are needed to determine the mechanisms by which endocrine and local IGF-1 regulate skeletal growth and bone size. Findings from our MrOS Sweden cohort show that in older men, serum IGF-1 is a predictor of incident fractures, more specifically, of the two most important fractures types, hip and vertebral fractures, in older men. This relationship between serum IGF-1 and risk of fracture is partly dependent on BMD. Still, further studies are needed to identify other mediators affecting this association.

\section{ACKNOWLEDGMENTS}

Our research described in this review was funded by the Swedish Research Council, the Swedish Foundation for Strategic Research, the ALF/LUA research grant in Gothenburg, the Lundberg Foundation, the Torsten and Ragnar Söderberg's Foundation, and the Novo Nordisk Foundation. We thank the MrOS study personnel for excellent research assistance and Anders Odén, Professor in biostatistics, for calculation of the Poisson regression using spline functions and of populationattributable risk. 


\section{REFERENCES}

Barrett-Connor, E., and GoodmanGruen, D. (1998). Gender differences in insulin-like growth factor and bone mineral density association in old age: the Rancho Bernardo Study. J. Bone Miner. Res. 13, 1343-1349.

Bennett, A. E., Wahner, H. W., Riggs, B. L., and Hintz, R. L. (1984). Insulin-like growth factors I and II: aging and bone density in women. J. Clin. Endocrinol. Metab. 59, 701-704.

Bonapace, G., Concolino, D., Formicola, S., and Strisciuglio, P. (2003). A novel mutation in a patient with insulinlike growth factor 1 (IGF1) deficiency. J. Med. Genet. 40, 913-917.

Center, J. R., Nguyen, T. V., Sambrook, P. N., and Eisman, J. A. (1999a). Hormonal and biochemical parameters in the determination of osteoporosis in elderly men. J. Clin. Endocrinol. Metab. 84, 3626-3635.

Center, J. R., Nguyen, T. V., Schneider, D., Sambrook, P. N., and Eisman, J. A. (1999b). Mortality after all major types of osteoporotic fracture in men and women: an observational study. Lancet 353, 878-882.

Garnero, P., Sornay-Rendu, E., and Delmas, P. D. (2000). Low serum IGF-1 and occurrence of osteoporotic fractures in postmenopausal women. Lancet 355, 898-899.

Giustina, A., Mazziotti, G., and Canalis, E. (2008). Growth hormone, insulin-like growth factors, and the skeleton. Endocr. Rev. 29, 535-559.

Govoni, K. E., Lee, S. K., Chung, Y. S., Behringer, R. R., Wergedal, J. E., Baylink, D. J., and Mohan, S. (2007a). Disruption of insulin-like growth factor-I expression in type IIalphaI collagen-expressing cells reduces bone length and width in mice. Physiol. Genomics 30, 354-362.

Govoni, K. E., Wergedal, J. E., Florin, L., Angel, P., Baylink, D. J., and Mohan, S. (2007b). Conditional deletion of insulin-like growth factor-I in collagen type lalpha2-expressing cells results in postnatal lethality and a dramatic reduction in bone accretion. Endocrinology 148, 5706-5715.

Janssen, J. A., Burger, H., Stolk, R. P., Grobbee, D. E., De Jong, F. H., Lamberts, S. W., and Pols, H. A. (1998). Gender-specific relationship between serum free and total IGF-I and bone mineral density in elderly men and women. Eur. J. Endocrinol. 138, 627-632.

Kanazawa, I., Yamaguchi, T., Yamamoto, M., Yamauchi, M., Yano, S., and Sugimoto, T. (2007). Serum insulinlike growth factor-I level is associated with the presence of vertebral fractures in postmenopausal women with type 2 diabetes mellitus. Osteoporos. Int. 18, 1675-1681.

Langlois, J. A., Rosen, C. J., Visser, M., Hannan, M. T., Harris, T., Wilson, P. W., and Kiel, D. P. (1998). Association between insulin-like growth factor I and bone mineral density in older women and men: the Framingham Heart Study. J. Clin. Endocrinol. Metab. 83, 4257-4262.

Munoz-Torres, M., Mezquita-Raya, P., Lopez-Rodriguez, F., Torres-Vela, E., De Dios Luna, J., and EscobarJimenez, F. (2001). The contribution of IGF-I to skeletal integrity in postmenopausal women. Clin. Endocrinol. (Oxf.) 55, 759-766.

Ohlsson, C., Mellstrom, D., Carlzon, D., Orwoll, E., Ljunggren, O., Karlsson, M. K., and Vandenput, L. (2011). Older men with low serum IGF-1 have an increased risk of incident fractures: the MrOS Sweden study. J. Bone Miner. Res. 26, 865-872.

Ohlsson, C., Mohan, S., Sjogren, K., Tivesten, A., Isgaard, J., Isaksson, O., Jansson, J. O., and Svensson, J. (2009). The role of liver-derived insulin-like growth factor-I. Endocr. Rev. 30, 494-535.

Orwoll, E. S. (2003). Toward an expanded understanding of the role of the periosteum in skeletal health. J. Bone Miner. Res. 18, 949-954.

Sjögren, K., Liu, J., Blad, K., Skrtic, S., Vidal, O., Wallenius, V., Leroith, D., Törnell, J., Isaksson, O., Jansson, J., and Ohlsson, C. (1999). Liverderived insulin-like growth factor I (IGF-I) is the principle source of IGF-I in blood but is not required for postnatal body growth in mice. Proc. Natl. Acad. Sci. U.S.A. 96, 7088-7092.

Sjögren, K., Sheng, M., Moverare, S., Liu, J., Wallenius, K., Tornell, J., Isaksson, O., Jansson, J., Mohan, S., and Ohlsson, C. (2002). Effects of liverderived insulin-like growth factor I on bone metabolism in mice. J. Bone Miner. Res. 17, 1977-1987.

Sugimoto, T., Nishiyama, K., Kuribayashi, F., and Chihara, K. (1997). Serum levels of insulin-like growth factor (IGF) I, IGF-binding protein (IGFBP)-2, and IGFBP-3 in osteoporotic patients with and without spinal fractures. J. Bone Miner. Res. 12, 1272-1279.

Walenkamp, M. J., Karperien, M., Pereira, A. M., Hilhorst-Hofstee, Y., Van Doorn, J., Chen, J. W., Mohan, S., Denley, A., Forbes, B., Van Duyvenvoorde, H. A., Van Thiel, S. W. Sluimers, C. A., Bax, J. J., De Laat, J. A., Breuning, M. B., Romijn, J. A., and Wit, J. M. (2005). Homozygous and heterozygous expression of a novel insulin-like growth factor-I mutation. J. Clin. Endocrinol. Metab. 90, 2855-2864.

Woods, K., Camacho-Hübner, C., Savage, M., and Clark, A. (1996). Intrauterine growth retardation and postnatal growth failure associated with deletion of the insulin-like growth factor I gene. N. Engl. J. Med. 335, 1363-1367.

Yakar, S., Liu, J., Stannard, B., Butler, A., Accili, D., Sauer, B., and Leroith, D. (1999). Normal growth and development in the absence of hepatic insulin-like growth factor
I. Proc. Natl. Acad. Sci. U.S.A. 96, 7324-7329.

Yakar, S., Rosen, C. J., Beamer, W. G., Ackert-Bicknell, C. L., Wu, Y., Liu, J. L., Ooi, G. T., Setser, J., Frystyk, J., Boisclair, Y. R., and Leroith, D. (2002). Circulating levels of IGF1 directly regulate bone growth and density. J. Clin. Invest. 110, 771-781.

Yakar, S., Rosen, C. J., Bouxsein, M. L. Sun, H., Mejia, W., Kawashima, Y., Wu, Y., Emerton, K., Williams, V., Jepsen, K., Schaffler, M. B., Majeska, R. J., Gavrilova, O., Gutierrez, M., Hwang, D., Pennisi, P., Frystyk, J., Boisclair, Y., Pintar, J., Jasper, H., Domene, H., Cohen, P., Clemmons, D., and Leroith, D. (2009). Serum complexes of insulin-like growth factor-1 modulate skeletal integrity and carbohydrate metabolism. FASEB J. 23, 709-719.

Conflict of Interest Statement: The authors declare that the research was conducted in the absence of any commercial or financial relationships that could be construed as a potential conflict of interest.

Received: 16 December 2011; accepted: 14 March 2012; published online: 27 March 2012.

Citation: Vandenput L, Sjögren $K$, Svensson J and Ohlsson C (2012) The role of IGF-1 for fracture risk in men. Front. Endocrin. 3:51. doi: 10.3389/fendo.2012.00051

This article was submitted to Frontiers in Bone Research, a specialty of Frontiers in Endocrinology.

Copyright (c) 2012 Vandenput, Sjögren, Svensson and Ohlsson. This is an openaccess article distributed under the terms of the Creative Commons Attribution Non Commercial License, which permits non-commercial use, distribution, and reproduction in other forums, provided the original authors and source are credited. 